REPORTS OF MORPHOLOGY
$\begin{gathered}\text { Official Journal of the Scientific Society of Anatomists, } \\ \text { Histologists, Embryologists and Topographic Anatomists } \\ \text { of Ukraine } \\ \text { journal homepage: https://morphology-journal.com }\end{gathered}$

\title{
Features of the interaction of indicators of peculiarities of personality and characteristics of the quality of life of pupils and student youth by the cluster analysis
}

\author{
Gzhegotsky M.R., Tymoschuk O.V.*, Cherkasov V.G. ${ }^{* *}$, Dmytrenko S.V. ${ }^{* * *}$, Shapoval O.M.*** \\ Danylo Halytsky Lviv National Medical University, Lviv, Ukraine \\ *Ivano-Frankivsk National Medical University, Ivano-Frankivsk, Ukraine \\ ${ }^{* *}$ Bogomolets National Medical University, Kyiv, Ukraine \\ ${ }^{* * *}$ National Pirogov Memorial Medical University, Vinnytsya, Ukraine
}

\section{ARTICLEINFO}

Received: 4 December, 2018

Accepted: 9 January, 2019

UDC: $159.923+364.1: 616-053.5 /$

$.82: 519.237 .8$

\section{CORRESPONDING AUTHOR}

e-mail: vrector_sp@meduniv.Iviv.ua Gzhegotsky M.R.

\begin{abstract}
Recently, while conducting scientific research in the field of theoretical and preventive medicine, biomedical preventive anthropology and statistical processing of their results, one of the leading places is the cluster analysis procedure, which involves the search for the patterns of grouping as research objects and their leading features in separate local plurals and subsets, that is, in separate clusters. Researches that provided for determining the leading characteristics of the quality of life and the peculiarities of the course of psychological adaptation processes based on the use of commonly accepted psychohygienic practice of personal questionnaires were conducted on the basis of educational institutions in Ivano-Frankivsk. Statistical analysis of the obtained data provided for the use of descriptive statistics and cluster analysis procedures using the licensed standardized application package of the multivariate statistical analysis "Statistica 6.1 for Windows" (license number BXXR901E245722FA). The results of the conducted research indicate the existence of an extremely stable structure of the identified groups, among which in all investigated cases, it necessary to note the cluster associated with the leading indicators of quality of life, which united in its structure characteristics of quality of life on the scales Bodily Pain (BP, Pain scale), Physical Functioning (PF, Physical Functioning scale), Mental Health (MH, Mental Health Scale), General Health (GH, General Health Scale), Vitality (VT, Viability Scale) and Social Functioning (SF, scale of social functioning), neuro-psychical cluster combining personal and situational anxiety, depressive and asthenic states, as well as an integral cluster that included in its structure the characteristics of quality of life on the scale of Role-Emotional (RE, role-playing role scale) and Role-Physical (RP, scale of role-physical functioning) and indicators of subjective control in health and disease and neuroticism. The obtained data should further find a proper place in the structure of diagnostic and preventive approaches to assess the state of health and functional state of the body of pupils and students.
\end{abstract}

Keywords: pupils and students, modern institutions of education, quality of life, mental adaptation, interaction, cluster analysis.

\section{Introduction}

Recently, while conducting scientific research in the field of theoretical and preventive medicine, biomedical preventive anthropology and statistical processing of their results, one of the leading places is occupied by cluster analysis procedures, which provide the search of grouping patterns as objects of research and their leading features in separate local sets and subsets, that is, into separate clusters $[4,17$, $18,19,20,22]$.
Indeed, a cluster is a group, a certain class, or a certain group of homogeneous units. Therefore, the main task of cluster analysis is to recognize the formation of homogeneous groups, classes, or associations in the multidimensional space of the studied features that are calculated $[2,8,14,15,16]$.

The homogeneity of the collectively is determined by the rule of calculation of a certain metric, which characterizes 
the degree of similarity of two separate units of the collectively. Such a metric can be the distance between them or the similarity factor. Units similar to the selected metrics define units as belonging to one type, ie as homogeneous. In this regard, the choice of metric is the nodal point of the cluster analysis, which determines the final variant of division of collectively into classes. Next, according to the features of the metric scale, a distance matrix with zero diagonal elements is formed, which is in fact the main information base of cluster analysis, with Euclidean and Manhattan distances being the most commonly used and popular metrics $[3,4,5,7,9]$.

Therefore, cluster analysis as a modern method of multidimensional statistical analysis is designed to provide objective spatial classification of identical objects, characterized by the presence of a certain set of indicators, and their subsequent meaningful grouping in a certain structured space based on the use of either agglomerational-hierarchical or divisional-iteration approaches $[1,4,6,10]$.

Thus, the methods of cluster analysis are quite versatile, involve the use of various algorithms for mathematical transformations, determine the strict observance of the accuracy of statistical procedures, and, at the same time, have extremely great prospects for carrying out statistical procedures of multidimensional classification of the studied objects during the implementation of medical and biological research, including the study of the relationship between the criteria of mental adaptation (MA), which is the process of establishing optimal about the relationship between personality and environment in the course of performance of human activity and quality of life (QoL) characteristics, which is a certain generalized integral characteristic of the physical, psychological, emotional and social functioning of the human body, which reproduces its subjective perception of its somatic and mental state in direct relation to the actual state of health $[11,13,21,22,23]$.

The purpose of the work is to establish the characteristics of the relationship between personality traits and characteristics of pupils and students youth according to the use of cluster analysis procedures.

\section{Materials and methods}

The research was conducted on the basis of a number of modern educational institutions in Ivano-Frankivsk, namely: school (boarding school) for gifted children from rural areas, professional lyceum of road transport and construction, music specialized school, financialcommercial cooperative college and Vasyl Stefanyk Precarpathian National University. During the performance of scientific work, 300 pupils and students were surveyed, 150 people each.

Performing comprehensive assessment of the characteristics of the course of MA in pupils and students led to the definition of such personality traits (PT), as the level of extraversion-introversion and neuroticism through the use of a personal questionnaire of Eysenck, the level of situational (SA) and personal (PA) anxiety - based on Spielberger's personal questionnaire, personality degree of expression of asthenic (AC) and depressive condition (DC) - during the use of personal questionnaire of Malkova and psychometric scale of Tsung, the level of expression of subjective control (LSC) through the use of a personal Rotter questionnaire [13].

Leading QoL indicators, which included data on the general health of pupils and students according to the scale General Health $(\mathrm{GH})$, the level of physical functioning of the organism according to the scale Physical Functioning (PF), the degree of influence of physical condition on the features of role functioning according to the Role-Physical scale (RP), the level of influence of emotional state on the role functioning of students and students according to the Role-Emotional scale (RE), the intensity of painful sensations that occur, according to the scale of Bodily Pain (BP), the degree of expression of indicators of vitality in accordance with the sense of fullness of forces, energy and stability according to a scale of Vitality (VT), and features self-assessment scale for mental health according to Mental Health scale $(\mathrm{MH})$, determined on the basis of the use of non-specific questionnaire QoL "SF-36 Health Status Survey" [11].

Finally, the prognostic evaluation of the results obtained in the previous stage of the scientific research involved the implementation of descriptive statistics and cluster analysis procedures based on the use of the licensed standardized statistical analysis software package "Statistica 6.1 for Windows" (license number BXXR901E245722FA).

\section{Results}

Considering the data obtained during the use of cluster analysis procedures among young women who studied at school, it was necessary to distinguish 3 leading clusters that characterized the features of the interconnections of the leading components of QoL and PT, namely: cluster № 1 (integral), which combined in its structure QoL characteristics according to the Role-Emotional (RE) and Role-Physical (RP) scales and the LSC indicators in health and disease and neuroticism, cluster № 2 (associated with leading QoL indicators), which combines the characteristics of QoL according to the Bodily Pain (BP), Physic al Functioning (PF), General Health $(\mathrm{GH})$, Mental Health $(\mathrm{MH})$, Social Functioning (SF) and Vitality (VT) scales, cluster № 3 (neuro-psychic), which included PA, SA, DC and AC indicators. Among the young women who studied at school, there were also 3 leading clusters, which characterized the features of the interconnections of the leading components QoL and PT, which included the cluster № 1 (integrated), which united in its structure QoL characteristics according to the Role-Emotional (RE) and Role-Physical (RP) scales and LSC indicators in health and disease and neuroticism, cluster № 2 (linked to the leading QoL indicators), combining QoL characteristics according to the Physical Functioning (PF), Bodily Pain (BP), Mental Health (MH), General Health 


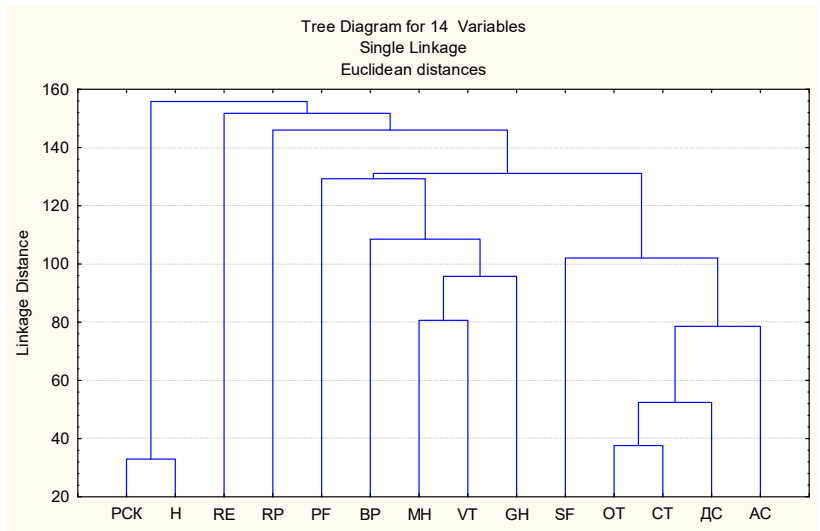

Fig. 1. Features of combining the main $Q o L$ and $P T$ survey clusters studied among young men who studied in schools.

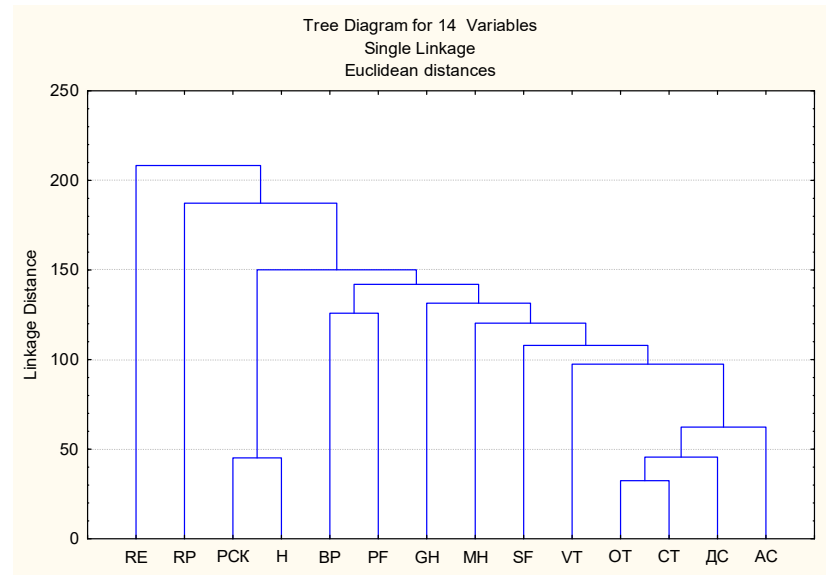

Fig. 2. Features of combining the main $\mathrm{QoL}$ and $\mathrm{PT}$ survey clusters studied among young women who studied in schools.

(GH), Vitality (VT) and Social Functioning (SF) scales, cluster № 3 (neuro-psychic), which included indicators PA, SA, DC and AC (Fig. 1-2).

In evaluating the results of the use of cluster analysis procedures among young women who studied under the conditions of professional lyceum, it was necessary to distinguish 3 leading clusters that characterized the features of the interconnections of the leading components of QoL and PT, namely: cluster № 1 (integral), which combined in its structure the characteristics of QoL according to the RoleEmotional (RE) and Role-Physical (RP) scales and the LSC indicators in the field of health and disease and neuroticism, cluster № 2 (associated with leading indicators QoL), which combined the QoL characteristics on the Bodily Pain (BP), Physical Functioning (PF), General Health (GH), Mental Health (MH), Social Functioning (SF) and Vitality (VT) scales, cluster № 3 (neuro-psychic), which included indicators PA, SA, DC and AC. Among the young men who studied under the conditions of professional lyceum, there were also 3 leading clusters, which characterized the features of the interconnections of the leading components QoL and PT, which included the cluster № 1 (integrated), which united in its QoL characteristics structure according to the Role-
Emotional (RE) and Role-Physical (RP) scales and health and disease and neuroticism LSC indicators, cluster № 2 (associated with leading QoL indicators), combining QoL characteristics according to the Physical Functioning (PF), Bodily Pain (BP), Mental Health (MH), Vitality (VT), General Health (GH) and Social Functioning (SF) scales, cluster № 3 (neuro-psychic), which included PA, SA, DC and AC indicators (Fig. 3-4).

Analyzing the results obtained from the use of cluster analysis procedures among young women who studied in terms of specialized school, it was also necessary to distinguish 3 leading clusters that characterized the features of the interconnections of the leading components of QoL and PT, namely: cluster № 1 (integral), which combined in its structure QoL characteristics on the Role-Emotional (RE) and Role-Physical (RP) scales and the health and disease and neuroticism LSC indicators, cluster № 2 (linked with the leading QoL indicators), which combined QoL features according to Physical Functioning (PF), Bodily Pain (BP), Mental Health (MH), Vitality (VT), General Health $(\mathrm{GH})$ and Social Functioning (SF) scales, cluster № 3 (neuro-psychic), which included indicators in its structure PA, SA, DC and AC. At the same time, the following three clusters, which

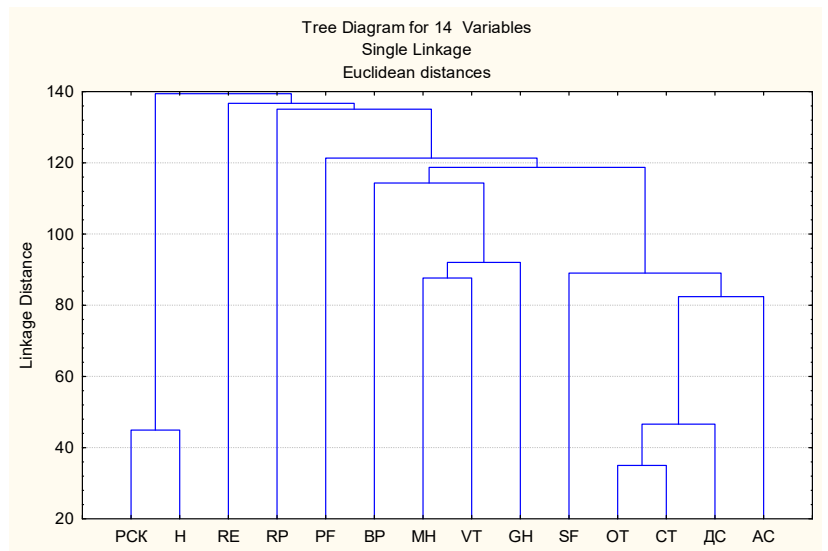

Fig. 3. Features of combining the main QoL and PT survey clusters studied among young men who studied in lyceum.

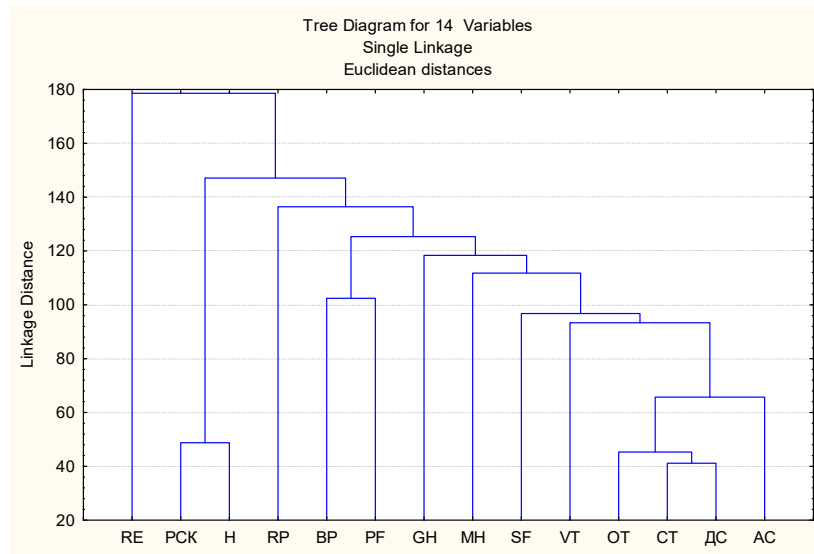

Fig. 4. Features of combining the main $\mathrm{QoL}$ and $\mathrm{PT}$ survey clusters studied among young women who studied in lyceum. 


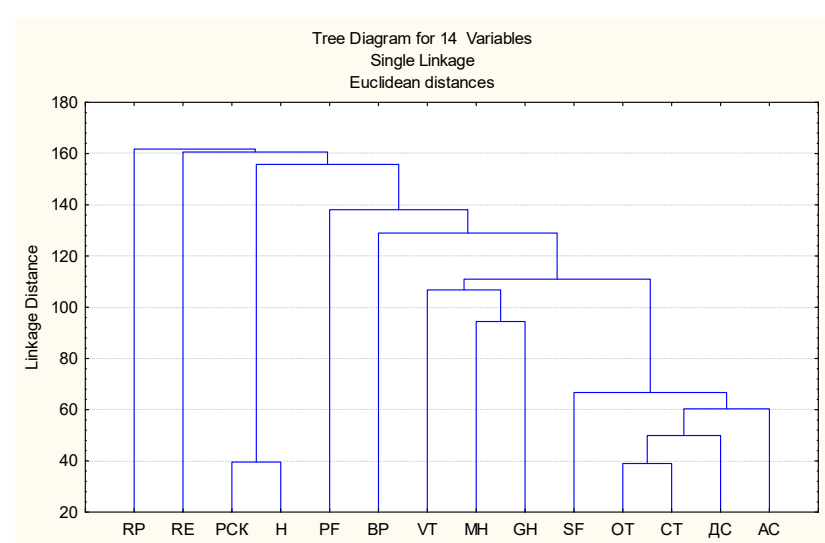

Fig. 5. Features of combining the main QoL and PT survey clusters studied among young men who studied in specialized school.

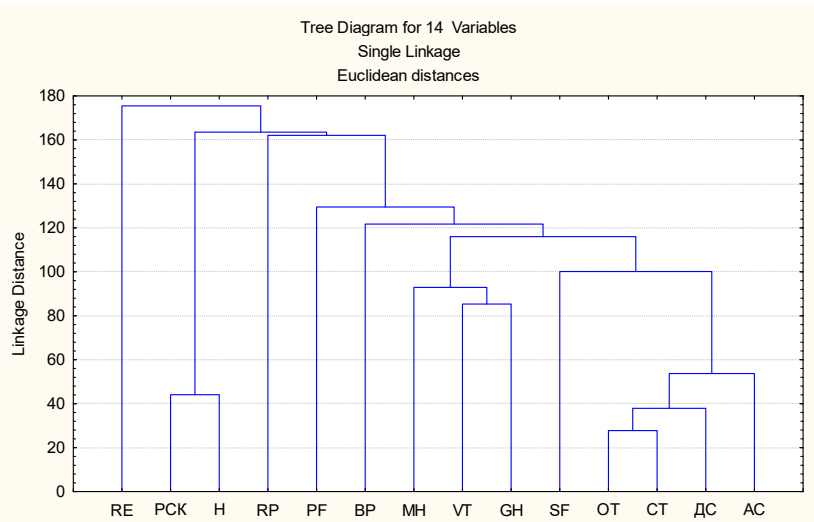

Fig. 6. Features of combining the main QoL and PT survey clusters studied among young women who studied in specialized school. characterized the features of the interconnections of the leading QoL and PT components which included cluster № 1 (integral), which combined in its structure QoL characteristics according to the Role-Emotional (RE) and Role-Physical (RP) scales and the health and illness and neuroticism LSC indicators, cluster № 2 (linked to leading QoLs indicators) that combines QoL characteristics according to the Physical Functioning (PF), Bodily Pain (BP), Vitality (VT), Mental Health (MH), General Health (GH) and Social Functioning (SF) scales, cluster № 3 (neuro-psychic), which included the indicators PA, SA, DC and AC (Fig. 5-6).

Considering the data obtained during the use of cluster analysis procedures among college young women, it was necessary to distinguish 3 leading clusters that characterized the features of the intrasystem connections of the leading components of QoL and PT, namely: cluster № 1 (integral), which combined in its structure QoL characteristics according to the Role-Emotional (RE) and Role-Physical (RP) scales and the LSC indicators in health and disease and neuroticism, cluster № 2 (associated with leading QoL indicators), which combined the characteristics of QoL according to the Bodily Pain (BP), Physical Functioning (PF), General Health (GH), Mental Health (MH), Vitality (VT) and Social Functioning (SF) scales, cluster № 3 (neuropsychic), which included PA, SA, DC and AC indicators.
Among the young men who studied in college, there were also three leading clusters that characterized the features of the interconnections of the leading QoL and PT components, which included the cluster № 1 (integrated), which combined in its structure QoL characteristics according to the RoleEmotional (RE) and Role-Physical (RP) scales and LSC indicators in health and disease and neuroticism, cluster № 2 (linked to the leading QoL indicators), combining QoL characteristics according to Physical Functioning (PF), Bodily Pain (BP), Vitality (VT), Mental Health (MH), General Health $(\mathrm{GH})$, Social Functioning (SF) scales, cluster № 3 (neuropsychic), which included indicators of PA, SA, DC and AC in its structure (Fig. 7-8).

Finally, in evaluating the results of the use of cluster analysis procedures among university young women, it was necessary to identify 3 leading clusters that characterized the intrinsic relationships of the leading components of QoL and PT, namely: cluster № 1 (integral), which combined in its structure QoL characteristics according to the RoleEmotional (RE) and Role-Physical (RP) scales and the LSC indicators in health and disease and neuroticism, cluster № 2 (associated with leading QoL indicators), which combined the characteristics of QoL according to the Bodily

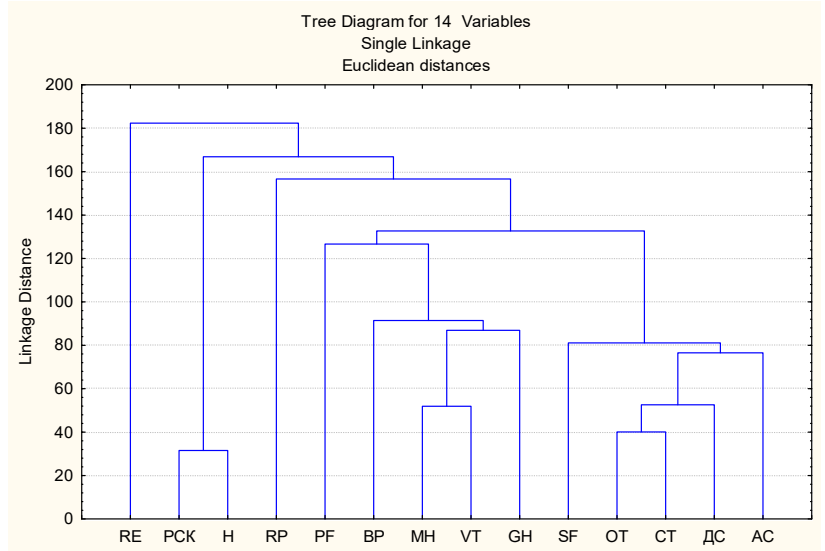

Fig. 7. Features of combining the main QoL and PT survey clusters studied among young men who studied in college.

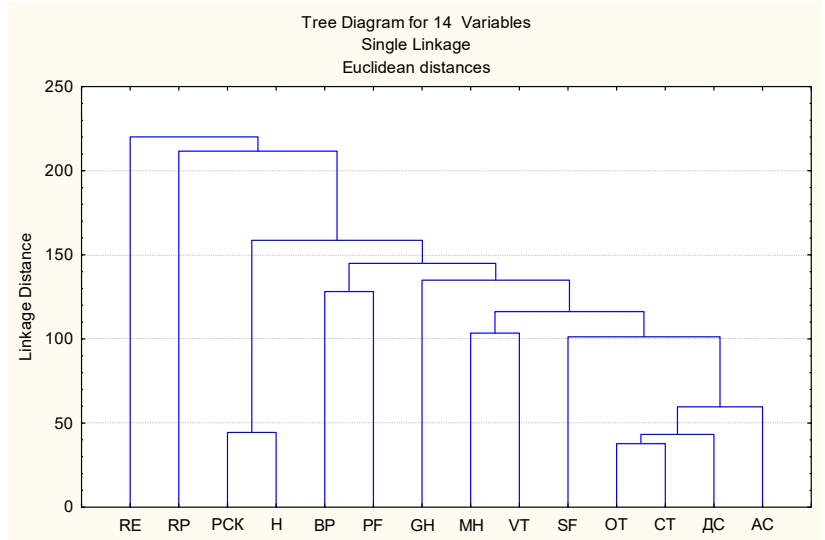

Fig. 8. Features of combining the main QoL and PT survey clusters studied among young women who studied in college. 


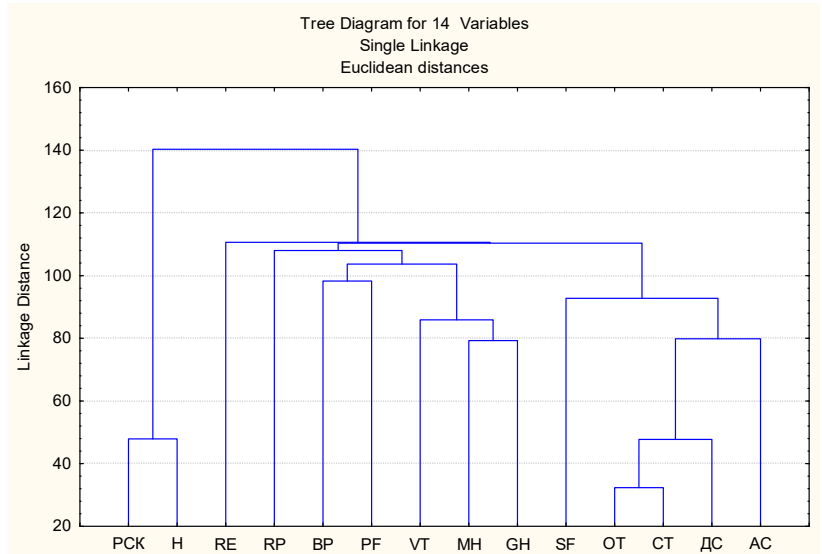

Fig. 9. Features of combining the main QoL and PT survey clusters studied among young men who studied in university.

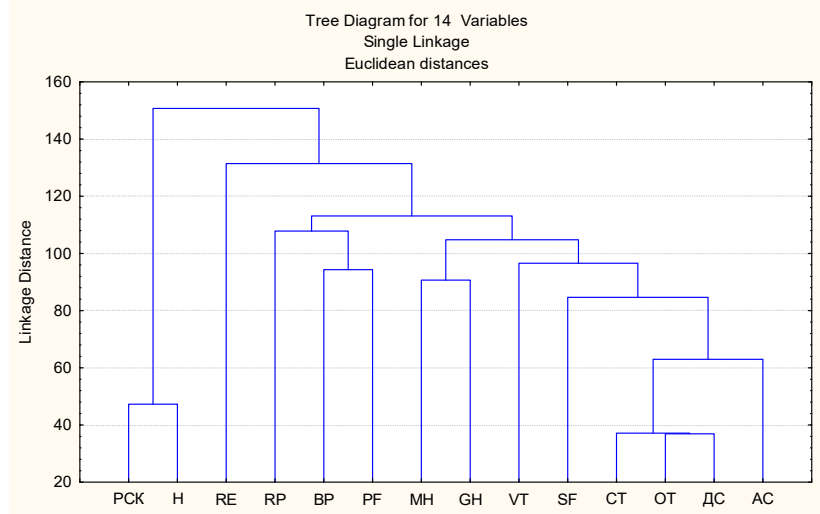

Fig. 10. Features of combining the main QoL and PT survey clusters studied among young women who studied in university.

Pain (BP), Physical Functioning (PF), Mental Health (MH), General Health (GH), Vitality (VT) and Social Functioning (SF) scales, cluster № 3 (neuro-psychic), which included in its structure PA, SA, DC and AC indicators. Among the young men who studied at the university, there were also three leading clusters that characterized the features of the interconnections of the leading components QoL and PT, which included the cluster № 1 (integrated), which combined in its structure QoL characteristics according to the RoleEmotional (RE) and Role-Physical (RP) scales and LSC indicators in health and disease and neuroticism, cluster № 2 (linked to the leading QoL indicators), which combined QoL characteristics according to the Bodily Pain (BP), Physical Functioning (PF), Vitality (VT), Mental Health (MH), General Health $(\mathrm{GH})$ and Social Functioning (SF) scales, cluster № 3 (neuro-psychic), which included indicators PA, SA, DC and AC (Fig. 9-10).

\section{Discussion}

Research data based on the use of cluster analysis procedures indicate that this approach is an extremely powerful tool for establishing any, but above all, functional relationships between the organism's adaptive resources and objective and subjective characteristics of health status.
In this context, it should be noted that this approach significantly expands and supplements the data presented in a number of studies published in recent years $[12,17,18$, $19,20,21,22]$. And, to be noted separately, determine the perspective of consideration in the development of modern diagnostic (development of methods of complex assessment of the state of adaptation resources of the body of young men and young women) and preventive (introduction of effective health-saving technologies and measures of psychophysiological impact on the body and psycho-hygienic changes in the body state of the body) approaches to the assessment of the state of health and functional state of the body of pupils and students QoL concept [11, 13, 21, 22, 23].

In general, it should be emphasized that the data obtained were marked by the presence of extremely stable results and, consequently, the structures of the identified groups, among which in all the investigated cases it was necessary to note a cluster related to the leading QoL indicators, which united in its structure the QoL characteristics by Bodily Pain (BP, Pain Scale), Physical Functioning (PF, Scale Of Physical Functioning), Mental Health (MH, Mental Health Scale), General Health (GH, General Health Scale), Vitality (VT, Vitality Scale) and Social Functioning (SF, Scale Of Social Functioning) scales, a neuro-psychic cluster that combines PA, SA, DC, and AC indicators, as well as an integrated cluster that included in its structure QoL characteristics according to the Role-Emotional (RE, Role-Emotional Function Scale) and Role-Physical (RP, Role of Physical Functioning Scale) scales and LSC indicators in health and illness and neuroticism.

\section{Conclusions}

1. The results of the studies show that there is an extremely stable structure of the identified groups, among which in all the cases studied, it was necessary to note a cluster associated with leading indicators of quality of life, which combined in its structure the characteristics of quality of life according to the scale of Bodily Pain (BP, Scale of Pain), Physical Functioning (PF, Scale of Physical Functioning), Mental Health ( $\mathrm{MH}$, Mental Health Scale), General Health (GH, General Vitality Scale), Vitality (VT, Vitality Scale), and Social Functioning (SF, social functioning scale), neuro-psychic cluster, combining indicators of personal and situational anxiety, depressive and asthenic states, as well as an integral cluster that included in its structure characteristics of quality of life according to the RoleEmotional (RE, Scale of Role Emotional Functioning) and Role-Physical scales (RP, Role Scale of Physical Functioning) and indicators of subjective control in health and illness and neuroticism.

2. The obtained data should further find a place in the structure of diagnostic (development of methods of complex assessment of the state of adaptation resources of the body of young men and young women) and preventive (introduction of effective health-saving technologies and 
measures of psychophysiological influence on the organism and psycho-hygienic correction of existing changes in the functional organism state) approaches to the assessment

\section{References}

[1] Abonyi, J., \& Feil, B. (2007). Cluster analysis for data mining and system identification. Boston, MA: Birkhäuser Basel.

[2] Aldenderfer, M. S., \& Blashfield, R. K. (1984). Cluster analysis. Newbury Park, CA: Sage Publications.

[3] Anderberg, M. R. (1973). Cluster analysis for applications. New York: Academic Press.

[4] Antomonov, M. Y. (2018). Mathematical processing and analysis of biomedical data. Kiev: MITs "Medinform".

[5] Arabie, P., Carroll, J. D., \& DeSarbo, W. S. (1987). Three-way scaling and clustering. Newbury Park, CA: Sage Publications.

[6] Everitt, B. S., Landau, S., \& Leese, M. (2001). Cluster analysis (4th ed.). London: Arnold.

[7] Jain, A. K., \& Dubes, R. C. (1988). Algorithms for clustering data. Englewood Cliffs, NJ: Prentice Hall.

[8] Jajuga, K., Sokolowski, A., \& Bock, H. H. (2002). Classification, clustering and data analysis. New York: Springer.

[9] Kaufman, L., \& Rousseeuw, P. J. (1990). Finding groups in data: An introduction to cluster analysis. New York: Wiley.

[10] Meli, M., \& Heckerman, D. (1998). An experimental comparison of several clustering and initialization methods. Redmond, WA: Microsoft.

[11] Novik, A. A., \& lonova, T. I. (Ed. Shevchenko, Yu. L.) (2007). Guidance on the study of the quality of life in medicine (2th ed.). M.: ZAO "OLMA Media Grupp".

[12] Polka, N. S., \& Serheta I. V. (2012). Actual problems of psychohygiene of children and adolescents: ways and perspectives of their solution (review of literature and own research). Journal NAMS of Ukraine, 18(2), 223-236.

[13] Raygorodskiy, D. Y. (2011). Practical psychodiagnostics. Techniques and tests. Samara: Publishing house "Bahrah-M".

[14] Rebrova, O. Y. (2006). Statistical analysis of medical data. Application of the Statistica software package. Moskva: MediaSfera.

[15] Rapkin, B. D., \& Luke, D. A. (1993). Cluster analysis in community of the state of health and functional state of the body of pupils and students.

research: Epistemology and practice. American Journal of Community Psychology, 21(2), 247-277. https://doi.org/ 10.1007/BF00941623

[16] Romesburg, H. C. (2004). Cluster analysis for researchers. North Carolina: Lulu.

[17] Serheta, I. V., Grigorchuk, L. I., \& Molchanova, O. P. (2002). Ways of optimization of professional adaptation of students to the conditions of study at a medical higher educational institution and their predictive value. Environment and health, 23(4), 57-61.

[18] Serheta, I. V., Bratkova, O. Y., Mostova, O. P., Panchuk, O. Y., \& Dudarenko, O. B. (2012). Scientific principles of psychohygienic diagnostics of the health of children, adolescents and youth. Environment and health, 64(4), 2125.

[19] Serheta, I. V. (2013). Prenosological changes in mental state, modern psychohygienic approaches to interpretation, diagnosis and evaluation. Scientific Journal of Health of Ukraine, 3(4), 36-49.

[20] Serheta, I. V., Panchuk, O. Y., Stoyan, N. V., Drezhenkova, I. L., \& Makarov, S. Y. (2016). University hygiene in the context of implementation of the "Law on Higher Education": physiological and hygienic bases, realities and ways of development. Environment and health, 80 (4), 46-52.

[21] Suharev, A. G., \& Serheta, I. V. (1996). Personal features of the body of modern teenagers and the ways of their correction. Hygiene and sanitation, 1, 29-31.

[22] Serdyuk, A. M., Polka, N. S., \& Sereta, I. V. (2012). Psychohygiene of children and adolescents suffering from chronic somatic diseases. Vinnitsya: Nova kniga.

[23] The WHOQOL Group. (1995). The World Health Organization Quality of Life assessment (WHOQOL): position paper from the World Health Organization. Soc. Sci. Med., 41, 1403-1409. https://doi.org/10.1016/0277-9536(95)00112-K

\section{ОСОБЛИВОСТІ ВЗАЄМОЗВ'ЯЗКУ ПОКАЗНИКІВ ОСОБЛИВОСТЕЙ ОСОБИСТОСТІ ТА ХАРАКТЕРИСТИК ЯКОСТІ ЖИТТЯ УЧНІВСЬКОЇ І СТУДЕНТСЬКОЇ МОЛОДІ ЗА ДАНИМИ КЛАСТЕРНОГО АНАЛІЗУ}

\section{Гжегоцький М. Р., Тимощук О. В., Черкасов В. Г., Дмитренко С. В., Шаповал О. М.}

Останнім часом під час проведення наукових досліджень в галузі теоретичної і профрілактичної медицини, біомедичної профрілактичної антропології та статистичного опрацювання їх результатів, одне з провідних місць займають процедури кластерного аналізу, що передбачають пошук закономірностей групування як об'єктів дослідження, так і їх провідних ознак в окремі локальні множини та підмножини, тобто в окремі кластери. Дослідження, що передбачало визначення провідних характеристик якості життя та особливостей перебігу процесів психічної адаптації на підставі використання загальноприйнятих у психогігієнічній практиці особистісних опитувальників, проводили на базі освітніх закладів м. ІваноФранківська. Статистичний аналіз отриманих даних обумовлював використання процедур описової статистики та кластерного аналізу із застосуванням ліцензійного стандартизованого пакету прикладних програм багатовимірного cmamuстичного аналізу "Statistica 6.1 for Windows" (ліцензійний № BXXR901E245722FA). Результати проведених досліджень засвідчують наявність надзвичайно стабільної структури виявлених угруповань, серед яких у всіх досліджуваних випадках необхідно відзначити кластер, пов'язаний із провідними показниками якості життя, що об'єднував у своїй структурі характеристики якості життя за шкалами Bodily Pain (BP, шкала болю), Physical Functioning (PF, шкала фрізичного фуунциінування), Mental Health (MH, шкала психічного здоров'я), General Health (GH, шкала загального здоров'я), Vitality (VT, uкала житmєздатності) i Social Functioning (SF, шкала соціального функціонування), нервово-психічний кластер, що поєднував у собі показники особистісної і ситуативної тривожності, депресивного і астенічного станів, а також інтегральний кластер, що включав у свою структуру характеристики якості життя за шкалами Role-Emotional (RE, шкала рольового емоційного функціонування) i Role-Physical (RP, шкала рольового фрізичного функціонування) та показники рівня суб'єктивного контролю у галузі здоров'я $і$ хвороби та нейротизму. Отримані дані мають у подальшому знайти належне місце в структурі діагностичних та профілактичних підходів до оцінки стану здоров'я та функціонального стану організму учнівської і студентської молоді. Ключові слова: учні і студенти, сучасні заклади освіти, якість життя, психічна адаптація, взаємозв'язок, кластерний аналіз. 


\section{ОСОБЕННОСТИ ВЗАИМОСВЯЗИ ПОКАЗАТЕЛЕЙ ЛИЧНОСТНЫХ ОСОБЕННОСТЕЙ И ХАРАКТЕРИСТИК КАЧЕСТВА ЖИЗНИ УЧЕНИЧЕСКОЙ И СТУДЕНЧЕСКОЙ МОЛОДЕЖИ В СООТВЕТСТВИИ С ДАННЫМИ КЛАСТЕРНОГО АНАЛИЗА \\ Гжегоцкий М. Р., Тимощук О. В., Черкасов В. Г., Дмитренко С. В., Шаповал Е. Н.}

В последнее время в ходе проведения научных исследований в области теоретической и профилактической медицины, биомедицинской профилактической антропологии и статистической обработки их результатов, одно из ведущих мест занимают процедуры кластерного анализа, предусматривающие поиск закономерностей группировки как объектов исследования, так и их ведущих признаков в отдельные локальные множества и подмножества, то есть в отдельные кластеры. Исследования, предусматривающие определение ведущих характеристик качества жизни и особенностей течения процессов психической адаптации на основе использования общепринятых в психогигиенической практике личностных опросников, проводились на базе образовательных заведений г. Ивано-Франковск. Статистический анализ полученных данных предусматривал использование процедур описательной статистики и кластерного анализа с применением лицензионного стандартизированного пакета прикладных программ многомерного статистического анализа "Statistica 6.1 for Windows" (лицензионный № BXXR901E245722FA). Результаты проведенных исследований свидетельствуют о наличии чрезвычайно стабильной структуры выявленных группировок, среди которых во всех исследуемых случаях необходимо выделить кластер, связанный с ведущими показателями качества жизни, объединяющий в своей структуре характеристики качества жизни по шкалам Bodily Pain (BP, шкала боли), Physical Functioning (PF, шкала фризического фрунционирования), Mental Health (MH, шкала психического здоровья), General Health (GH, шкала общего здоровья), Vitality (VT, шкала жизнеспособности) и Social Functioning (SF, шкала социального функционирования), нервно-психический кластер, сочетающий в своей структуре показатели личностной и ситуативной тревожности, депрессивного и астенического состояний, а также интегральный кластер, включающий в свою структуру характеристики качества жизни по шкалам Role-Emotional ( $R E$, шкала ролевого эмоционального фрункционирования) и Role-Physical (RP, шкала ролевого фризического фрункционирования) и показатели уровня субъективного контроля в области здоровья и болезни, а также нейротизма. Полученные данные в дальнейшем должны найти надлежащее место в структуре диагностических и профилактических подходов к оценке состояния здоровья и функционального состояния организма ученической и студенческой молодежи.

Ключевые слова: учащиеся и студенты, современные учреждения образования, качество жизни, психическая адаптация, взаимосвязь, кластерный анализ. 